\title{
ДИАГНОСТИРОВАНИЕ ИНСАЙДЕРСКОЙ ТОРГОВЛИ \\ В ПЕРИОД ПЕРЕД СЛУЧАЯМИ \\ АДМИНИСТРАТИВНОГО ДАВЛЕНИЯ НА БИЗНЕС
}

Е. В. Чиркова ${ }^{1}$ В. Петров ${ }^{2}$

В статье представлены результаты исследования инсайдерской торговли в периоды, предшествую-шие случаям административного давления на бизнес, на российском фондовом рынке в 2000-2014 годах. Исследование базируется на анализе накопленной избыточной доходности в период до публикации соответствующего новостного события. В рамках исследования мы проанализировали 71 новость. Нами не было диагностировано значительной по масштабам инсайдерской торговли шв периоды, предшествовавшие случаям административного давления на бизнес со стороны представителей исполнительной и законодательной властей Российской Федерации. Размер избыточной доходности в данном случае составил $-0,4 \% \ldots-0,6 \%$ в зависимости от применяемой модели. Мы обнаружили наличие значительной по масштабам инсайдерской торговли в периоды, предшествовавшие случаям административного давления на бизнес со стороны представителей силовых структур (-8,2\%...-10,4\%). Реакция рынка в обоих случаях была значительной. Мы диагностировали наличие меньшей по масштабам инсайдерской торговли, чем в случае действий представителей силовых структур, в периоды, предшествовавшие случаям административного давления на бизнес со стороны представителей таких служб исполнительной власти, как ФНС и ФАС (-2,3\%...-4,4\% и -3,9\%...-4,4\% соответственно). При этом рынок слабо реагировал на случаи административного бдавления со стороны представителей данных государственных органов. Кроме того, мы пришли к выводу, что ужесточение законодательства Российской Федерации в сфере противодействия инсайодерской торговле в 2010-2013 гг. не дало желаемого результата и масштабы инсайдерской торговли чна российском фондовом рынке увеличились.

Ключевые слова: инсайдерская торговля, совокупная избыточная доходность, административное давление.

JEL: G10, G14, G19.

\section{Введение}

В настоящее время тема инсайдерской торговли на финансовых рынках вызывает большой интерес среди ученых-финансистов. При этом вопрос наличия инсайдерской торговли в период, предшествующий случаям административного давления на бизнес, остается практически неизученным ввиду отсутствия большого количества случаев административного давления на бизнес в развитых и развивающихся странах.

Таким образом, особый интерес представляют случаи административного давления на бизнес именно на российском рынке. Во-первых, государственное вмешательство в ведение бизнеса в России имеет место намного чаще, чем в развитых странах. Во-вторых, в противоположность развитым странам, где за инсайдерскую торговлю предусмотрены большие штрафы и лишение свободы и где возбуждается большое количество уголовных дел по обвинению в инсайде, в России до последнего времени за инсайдерскую торговлю было предусмотрено лишь административное наказание, да и оно применялось крайне редко. В результате инсайдерская торговля в периоды, предшествующие случаям административного давления, может быть широко распространена на российском рынке.

В июле 2010 г. вступил в силу Федеральный закон от 27.07.2010 № 224-Ф3 «О противодействии неправомерному использованию инсайдерской информации и манипулированию рынком и о внесении изменений в отдельные законодательные акты Российской Федерации», который предусматривает административную и уголовную ответственность за инсайдерскую торговлю. В связи с этим является актуальным выявление случаев, в которых можно подозревать наличие инсайдерской торговли на российском фондовом рынке.

В течение последнего десятилетия большое количество российских компаний подвергалось административному давлению со стороны представителей государства и различных государственных

1. Кандидат экономических наук, Доцент, Департамент Финансов, Экономический факультет НИУ ВШЭ.

2. Аспирант, Департамент Финансов, Экономический факультет НИУ ВШЭ. 
служб. Самыми громкими фактами административного давления, пожалуй, являются заявления В.В. Путина в отношении компании «Яндекс» (24.04.2014) и компании «Мечел» (24.07.2008), а также комплекс принятых мер и заявлений в связи с «делом Башнефти» в 2014 г.

В рамках данного исследования диагностируется наличие инсайдерской торговли в периоды, пред-

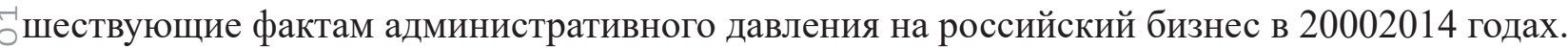

\section{Результаты эмпирических исследований инсайдерской торговли}

\section{Результаты исследований декларируемой инсайдерской торговли}

В ряде работ, исследующих инсайдерскую торговлю, применяется анализ декларируемой (то есть слегальной) инсайдерской торговли для целей выявления избыточной доходности (abnormal return, AR). Большинство авторов, анализирующих американский фондовый рынок, делают вывод о возможности получения избыточной доходности инсайдерами и/или участниками рынка, «подражаю-щих» им [Jaffe, 1974b; Finnerty, 1976; Seyhun, 1986; Rozeff, Zaman, 1988].

ОНа рынках других развитых и развивающихся стран также была обнаружена положительная избы() точная доходность при инсайдерской торговле. Так, Бхаттачарья и Даук [Bhattacharya, Dauk, 2002], писследовав 103 страны, в которых функционирует фондовый рынок, обнаружили, что масштабы 굳ли зависели не столько от наличия законодательства по противодействию инсайду, сколь-ко от его применения. В статьях [King, Roell, 1989; Pope et al., 1990; Fidrmuc et al., 2006] авторы манализировали британский фондовый рынок и обнаружили избыточную доходность инсайдерских ғсделок, как по покупке, так и по продаже ценных бумаг. Авторы статьи [Del Brio et al., 2002] исс следовали испанский фондовый рынок за период с 1992 по 1996 год, когда инсайдерская торговля ऽыла запрещена, но на практике не преследовалась, и обнаружили, что инсайдеры получают избы立точную доходность, в то время как инвесторы, «подражающие» им - нет. Чеук и др. [Cheuk et al., $₫ 2006]$ проанализировали фондовый рынок Гонконга и пришли к выводу о том, что корпоративные инсайдеры в Гонконге зарабатывали избыточную доходность от сделок как по продаже, так и по покупке ценных бумаг. Похожие выводы были сделаны в работах [Wisniewski, Bohl, 2005] и [Gurgul, Majdosz, 2007] на данных польского фондового рынка и [Betzer, Theissen, 2009] на данных фондового рынка Германии. В недавней работе с анализом голландского фондового рынка [Derguse, Jong, Lefebre, 2009] была выявлена избыточная доходность в периоды, следующие за крупными покупками корпоративных инсайдеров, в особенности для небольших компаний.

Многие авторы, исследовавшие инсайдерскую торговлю на рынках как развитых, так и развивающихся стран, обнаружили, что прибыльная инсайдерская торговля имеет место в основном в случае небольших компаний [Seyhun, 1986; Rozeff, Zaman, 1988; Wong et al., 2000; Lakonishok, Lee 2001; Etebari et al., 2004; Zingg et al., 2007; Clements, Singh, 2011]. Авторы исследования [Wong, Chung, $\mathrm{Wu}, 2000]$, проанализировали инсайдерскую торговлю в 1991-1993 гг. на Гонконгском фондовом рынке и обнаружили, что положительная избыточная доходность наблюдалась только в случаях покупки акций небольших и, как правило, семейных. К схожему результату пришли авторы статьи [Zingg, Lang, Wyttenbach, 2007], исследовавшие инсайдерскую торговлю на фондовом рынке Швейцарии. Авторы [Etebari, Tuirani-Rad, Gilbert 2004] исследовали инсайдерскую торговлю на фондовом рынке Новой Зеландии в 1995-2001 гг. и обнаружили высокую избыточную доходность, зарабатываемую инсайдерами в течение года после сделки, как на покупках, так и на продажах акций. Причем наиболее высокие доходности наблюдались в случае небольших компаний. Лаконишок и Ли [Lakonishok, Lee, 2001], исследовав все сделки инсайдеров на американских биржах NYSE, Amex и NASDAQ в 19751995 гг., обнаружили, что инсайдеры обладают способностью предсказывать движение цен акций, особенно в случае маленьких компаний, при этом сделки по покупкам акций приносили большую доходность, нежели сделки продажам.

\section{Результаты исследований недекларируемой инсайдерской торговли}

Еще один способ изучения инсайдерской торговли - анализ информации о доказанных или предполагаемых случаях инсайдерской торговли. Так, результаты исследования случаев инсайдерской 
торговли в США, доказанных SEC в период 1980-1989 гг., свидетельствуют о наличии кумулятивной избыточной доходности (CAR - cumulative abnormal return) в размере 6,85\% [Meulbroek, 1992]. В период торгов инсайдеров накопленная избыточная доходность за период, предшествующий корпоративному событию, составила $40-50 \%$ от кумулятивной избыточной доходности в день публиfкации новости. Объемы торгов также превышали ожидаемый уровень в дни торговли инсайдеров.

Также существует широкий пласт работ, анализирующих предполагаемое наличие инсайдерской О 1981; Jarrell, Pinkerton, 1989; Radd, Wu, 1995; Meulbroek, Hart, 1997; Jabbour, Jalilvand, Switzer, 2000; Agarwal, Singh, 2006; Ching et al., 2006; Clements, Singh, 2011]. В данных статьях авторы обнаруживают положительную избыточную доходность накануне важных корпоративных событий. Так, в работе [Keown, Pinkerton, 1981], авторы проанализировали сделки M\&A на американском рынке в 1975-1978 гг. и обнаружили положительную накопленную избыточную доходность начиная с 25го дня до анонсирования сделки. Ко дню объявления о сделке доходность достигала 13\%, в день анонсирования $-25 \%$, т.е. около половины CAR приходилось на период до анонсирования. Объемы торгов перед объявлением о сделке также росли. Клементс и Сингх [Clements, Singh, 2011] хпровели сравнение американского фондового рынка тридцатилетней давности с современным, где (-) регулирование ужесточилось в начале 2000-х гг. Авторы делают вывод о том, что более жесткое ᄂзаконодательство приводит к уменьшению масштабов недекларируемой инсайдерской торговли.

\section{Результаты исследований не декларируемой инсайдерской торговли на фондовом рынке Российской Федерации}

В последнее время было проведено несколько исследований инсайдерской торговли на российском чрынке акций. Чиркова и Агамян [Чиркова, Агамян, 2015] в своей работе приходят к выводу о наटличии инсайдерской торговли на российском фондовом рынке в период до объявлении о сделках ळ M\&A в 2006-2013 гг. (средний CAR = 15\%). Авторы обнаружили, что на период, предшествующий объявлению (появлению слухов) о сделке, приходится две трети роста CAR, тогда как в CША - только треть. В работе [Чиркова, Петров, 2015] авторы, анализируя инсайдерскую торговлю в период корпоративного конфликта акционеров ОАО «ВымпелКом» в 2005-2013 гг., обнаружили наличие масштабной инсайдерской торговли в период, предшествующий публичным заявлениям, сделанным представителями «Альфа-Груп», и не обнаружили инсайдерской торговли в период до публичных заявлений, сделанных представителями Telenor. Также авторы диагностировали крупную по масштабам инсайдерскую торговлю в период до вынесения судебных решений российскими судами, при этом в период до вынесения судебных решений судами иностранных юрисдикций инсайдерской торговли обнаружено не было. Кроме того, авторы пришли к выводу о наличии масштабной инсайдерской торговли в периоды, предшествовавшие государственному вмешательству в ход акционерного конфликта. На текущий момент затрагиваемая авторами исследования тема наличия инсайдерской торговли в периоды, предшествовавшие случаям административного давления на бизнес, представляется недостаточно изученной ввиду отсутствия большого количества случаев административного давления на бизнес в развитых и развивающихся странах.

Таким образом, большинство авторов, исследующих декларируемую инсайдерскую торговлю, приходят к выводу, что инсайдеры могут получать положительную избыточную доходность как на развитых, так и на развивающихся рынках. Ряд исследователей обнаруживает отрицательную взаимосвязь между доходностью инсайдерской торговли и размером компании. Немногочисленные исследования доказанных случаев инсайдерской торговли также показали наличие избыточной доходности у инсайдеров. Их авторы подсчитали, что примерно половина CAR была реализована до дня объявления о сделке. Практически все исследователи обнаружили инсайдерскую торговлю перед объявлением о сделках M\&A. При этом авторы отмечают, что в США в среднем 1/3 роста CAR приходится на период до дня объявления о сделке. Во многих работах была обнаружена взаимосвязь между масштабами инсайдерской торговли и жесткостью законодательства в сфере противодействия инсайдерской торговле. Зарубежными авторами до сих пор затрагивался вопрос наличия инсайдерской торговли в периоды, предшествующие случаям административного давления на бизнес, в силу отсутствия большого количества случаев административного давления на бизнес в развитых и в большинстве развивающихся странах. 


\section{Методология эмпирического анализа}

Диагностирование случаев инсайдерской торговли в данном исследовании проводилось методом анализа события (event study) через анализ отклонения наблюдаемой доходности акции компании $\frown$ В период до публикации новости от ожидаемой инвесторами доходности. Для расчета доходности ○े нами использовались цены закрытия торгового дня.

-Доходность акций анализируемых компаний рассчитывалась по формуле:

$\boldsymbol{R}_{i t}=\frac{\left(\boldsymbol{S}_{t}+\boldsymbol{D}_{\boldsymbol{t})}\right.}{\boldsymbol{S}_{t-1}}-1$,

где $S_{\mathrm{t}}$ и $S_{t-1}$ - цена акции в момент $t$ и $t-1 ;-$ уплаченные дивиденды в момент $t$.

重Цены акций анализируемых компаний, взятые из баз данных Bloomberg Professional и Capital IQ, ऽуже были скорректированы (создателями базы) с учетом выплаченных дивидендов. Кроме того, они учитывали эффект сплита акций. В качестве бенчмарка рыночной доходности нами был вы○бран индекс ММВБ.

Для целей проверки полученных результатов при расчете ожидаемой доходности нами были ис(-) пользовано два статистических метода: рыночная модель (market model) и скорректированная рыᄃночная модель (market adjusted model).

^Рыночная модель основана на предположении о сохранении линейной зависимости между доходбіностью рынка и доходностью рассматриваемой ценной бумаги в окне наблюдения (event window). ${ }_{\vec{\gamma}}^{m} R_{i t}=a_{i}+\beta_{i} R_{m t}$,

где $R_{m t}$ - рыночная доходность в периоде $t ; \beta_{\mathrm{i}}$ измеряет чувствительность доходности акций к средней рыночной доходности для события $i ; a_{i}$ измеряет доходность, не объясненную рынком. При

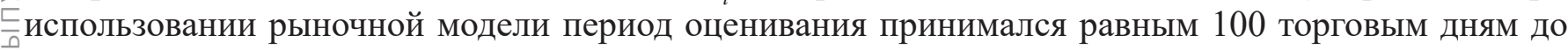

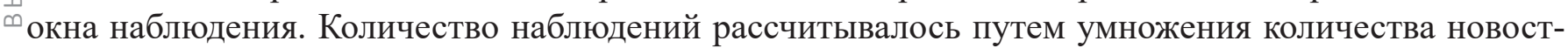
ных событий на количество торговых дней в окне события (10 дней).

Скорректированная рыночная модель представляет собой частный случай рыночной модели, где $a_{i}=0, \beta_{\mathrm{i}}=1$. В этом случае ожидаемая доходность акций компании представляет собой среднюю рыночную доходность в момент времени $t$.

$R_{i t}=R_{m e}$

где $R_{i t}$ - рыночная доходность в период $\mathrm{t}$.

Нами был использован следующий алгоритм расчета показателя кумулятивной избыточной доходности (cumulative abnormal return, CAR):

1) расчет избыточной доходности акций компании за каждый день в окне события:

$\boldsymbol{R}_{i t}=a_{i}+\beta_{i} \hat{\boldsymbol{R}}_{\boldsymbol{m} t}$,

где $R_{i t}$ - доходность акций компании в периоде $\mathrm{t}$;

$\hat{\boldsymbol{R}}_{\boldsymbol{i t}}$ - ожидаемая доходность акций компании в периоде t;

2) расчет кумулятивной (или совокупной) избыточной доходности акций компании в окне события:

$\operatorname{CAR}_{i}^{(x, y)}=\sum_{T=x}^{y} A R_{i}^{T}$

где (х,у) - продолжительность окна события.

Расчет избыточной доходности проводился для окна события

$(-10 ; 0)$, где 0 - дата публикации новости.

Средние значения кумулятивных избыточных доходностей по конкретным подгруппам использовались для проверки гипотез. После расчета кумулятивных избыточных доходностей по различным подгруппам была проведена проверка статистической значимости полученных результатов при помощи критерия t-статистики. 


\section{Анализ инсайдерской торговли в периоды, предшествующие случаям административного давления на бизнес}

\section{Характеристика выборки}

В исследовании диагностируется наличие инсайдерской торговли в период, предшествующий публикации новостей, связанных с административным давлением на бизнес. Список новостей, связанных с административным давлением на бизнес в 2000-2014 гг. с датой и временем их публикации в СМИ был составлен путем ручной выборки авторами статьи. Для каждого новостного события нами были рассчитаны доходность акций после выхода новости и совокупная избыточная шдоходность до публикации.

Все факты административного давления нами были разделены на четыре основных группы:

1. заявления, сделанные представителями власти;

2. заявления, сделанные представителями силовых структур;

3. заявления, сделанные представителями ФАС;

4. заявления, сделанные представителями ФНС.

Из первоначальной выборки нами были отброшены все «положительные» события. В результате мы получили 71 новостное событие. В последующем данные новостные события были разделены на 4 категории для целей тестирования гипотез (табл. 1).

Таблииа 1

Обозначения отдельных категорий новостей

\begin{tabular}{|c|c|c|c|c|}
\hline \multicolumn{2}{|c|}{ Название категории новостей } & Обозначение группы & Количество новостей & Количество событий ${ }^{1}$ \\
\hline \multicolumn{2}{|c|}{ Представители власти } & 1 & 19 & 36 \\
\hline \multicolumn{2}{|c|}{ Представители силовых структур } & 2 & 13 & 17 \\
\hline \multicolumn{2}{|l|}{ Представители ФАС } & 3 & 17 & 32 \\
\hline Представители ФНС & 4 & 22 & 22 & \\
\hline
\end{tabular}

Полный список новостей с датой публикации приведен в Приложении 1.

\section{Тестируемье гипотезы}

Для целей диагностирования инсайдерской торговли в период административного давления на бизнес нами были протестированы следующие гипотезы.

Гипотеза 1. Инсайдерская торговля присутствует в периоды, предшествующие фактам административного давления на бизнес представителями представителей власти.

Гипотеза 2. Реакция рынка на административное давление на бизнес со стороны представителей власти превышает аналогичную реакцию в случаях административного давления на бизнес со стороны представителей ФНС, ФАС и различных силовых структур.

Гипотеза 3. Масштабы инсайдерской торговли уменьшились после принятия (июль 2010 г.) и вступления с силу (январь 2011 г.) закона №224-Ф3 «О противодействии неправомерному использованию инсайдерской информации и манипулированию рынком», предусматривающего как административную (начиная с 27 июля 2011 г.), так и уголовную ответственность за инсайдерскую торговлю (начиная с 27 июля 2013 г.).

В рамках проверки гипотезы 1 анализировались значения и статистическая значимость средней избыточной доходности в периоды, предшествовавшие случаям административного давления на бизнес со стороны представителей власти. Также мы сравнивали значения и статистическую значимость избыточной доходности в периоды, предшествовавшие случаям административного давления на бизнес представителями различных властных структур.

1. Количество событий отличается от количества новостей в силу возможного влияния 1 новости на цену акций нескольких компаний. 
В рамках проверки гипотезы 2 сравнивались значения фактической доходности в день публикации новости об административном давлении на бизнес представителями различных государственных структур.

В рамках проверки гипотезы 3 сравнивались значения и статистическая значимость средней изббыточной доходности при административном давлении на бизнес в период до и после ужесточения законодательства по борьбе с инсайдерской торговлей в Российской Федерации.

\section{Результаты эмпирического исследования}

Проверка гипотезы 1. Анализ результатов, представленных в табл. 2, позволяет диагностировать шналичие инсайдерской торговли в периоды, предшествовавшие случаям административного давлениия на бизнес со стороны представителей законодательной и исполнительной власти.

Таблииа 2

Результаты исследования накопленной избыточной доходности в случаях административного давления со стороны представителей законодательной и исполнительной власти

\begin{tabular}{|c|c|c|}
\hline & Рыночная модель & $\begin{array}{c}\text { Скорректированная рыночная } \\
\text { модель }\end{array}$ \\
\hline CAR & $-0,6 \% * * *$ & $-0,4 \% * * *$ \\
\hline t-статистика & 9,17 & 5,96 \\
\hline Количество наблюдений & 360 & 360 \\
\hline \multicolumn{3}{|l|}{ Справочно: } \\
\hline Реакция рынка & $-2,78 \%$ & $-2,78 \%$ \\
\hline $\begin{array}{l}* * * \\
* * \\
*\end{array}$ & $\begin{array}{l}\text { - результат значим но } \\
\text { - результат значим но } \\
\text { - результат значим на }\end{array}$ & $\begin{array}{l}\text { ом уровне. } \\
\text { ом уровне. } \\
\text { ном уровне }\end{array}$ \\
\hline
\end{tabular}

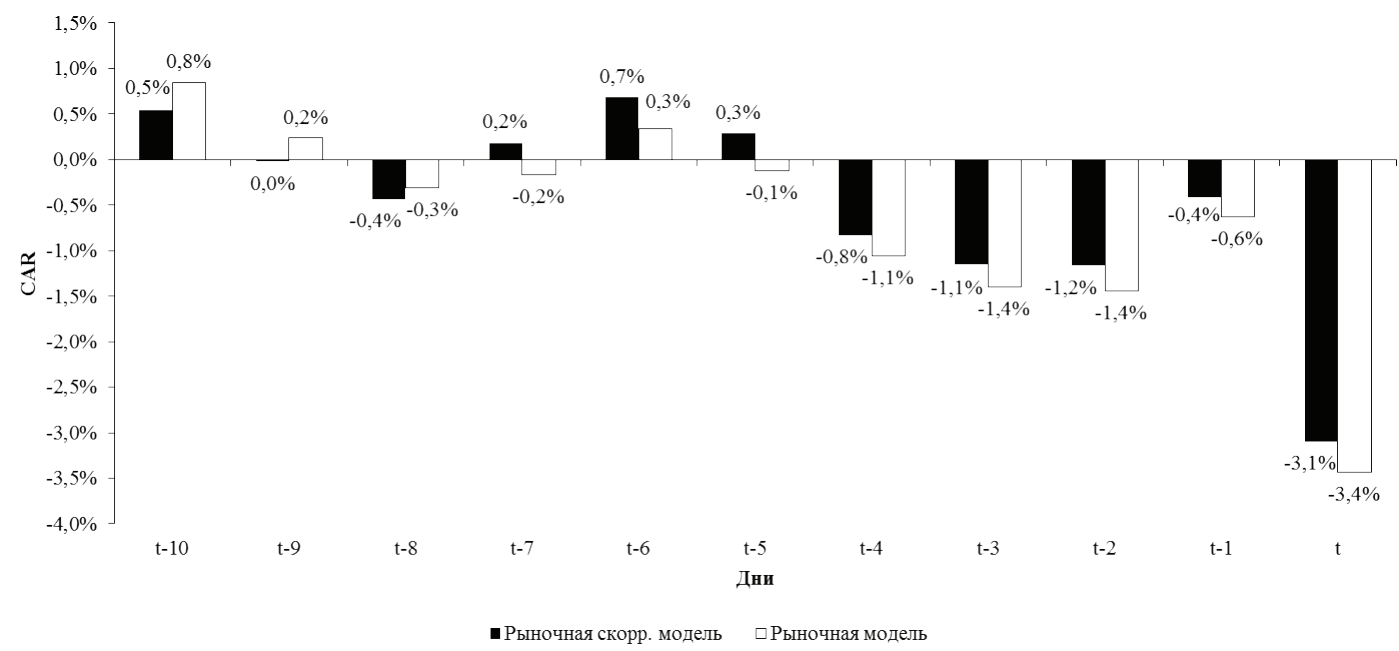

Рисунок 1. Динамика накопленной избыточной доходности в случаях административного давления со стороны представителей законодательной и исполнительной власти

При этом масштабы данной торговли незначительны: совокупная избыточная доходность составила $-0,4 \% \ldots-1,4 \%$ в зависимости от применяемой модели оценки избыточной доходности. Так, совокупная избыточная доходность акций компании Yandex за 10 дней, предшествовавших заявлению Президента Российской Федерации Владимира Путина от 24.04.2014 о том, что, Yandex, подобно большинству интернет-проектов, начинался как проект с западным влиянием (новость 1.6), составила $-2,7 \% \ldots-3,2 \%$. Цена акций компании «Яндекс» при этом упала на 5,4\%.

После внесения в Госдуму 15.01.2014 блока законопроектов, направленных на усиление регулирования в области денежных переводов (новость 1.7), цена акций компании Qiwi на бирже NASDAQ упала на 16,5\%. В свою очередь совокупная избыточная доходность за 10 дней, предшествовавших событию, при этом составила $0,4 \% \ldots-2,4 \%$.

Из данных табл. 3 видно, что избыточная доходность по результатам применения двух моделей оценки избыточной доходности составляет $-8,2 \% \ldots-10,4 \%$ в период, предшествующий случаям ад- 
министративного давления на бизнес со стороны представителей силовых структур, что говорит о наличии инсайдерской торговли при административном давлении данного типа. Так, в частности, совокупная избыточная доходность акций компании «Башнефть» за 10 дней, предшествовавших вызову на допрос в Следственный Комитет крупнейшего акционера АФК «Система» Владимира 들шенкова 23.07.2014 по уголовному делу о приватизации нефтяной компании «Башнефть» (но^ вость 2.4), составила $-9,8 \% \ldots-13,7 \%$ в зависимости от применяемой модели определения избыточ¡ной доходности.

Таблица 3

Результаты исследования накопленной избыточной доходности в случаях административного давления со стороны представителей силовых структур

$\frac{\text { CAR }}{\text { t-статистика }}$

Количество наблюдений Справочно:

Реакция рынка

Рыночная модель
$-10,4 \%$ ***
28,35

170

$-2,43 \%$
Скорректированная рыночная модель

$$
-8,2 \% * * *
$$

25,83

170

$-2,43 \%$

***-результат значим на 1\%-ном уровне.
** - результат значим на 5\%-ном уровне.
* - результат значим на 10\%-ном уровне.

Еще одним примером может служить новость о том, что сотрудники МВД 12.03.2014 задержали основного владельца ЧТПЗ Андрея Комарова по подозрению в даче взятки (новость 2.7), после 文чего стоимость акций компании упала на 6,4\%. Совокупная избыточная доходность за 10 дней, 爻предшествовавших данному событию, составила $-0,6 \% \ldots-11,8 \%$.

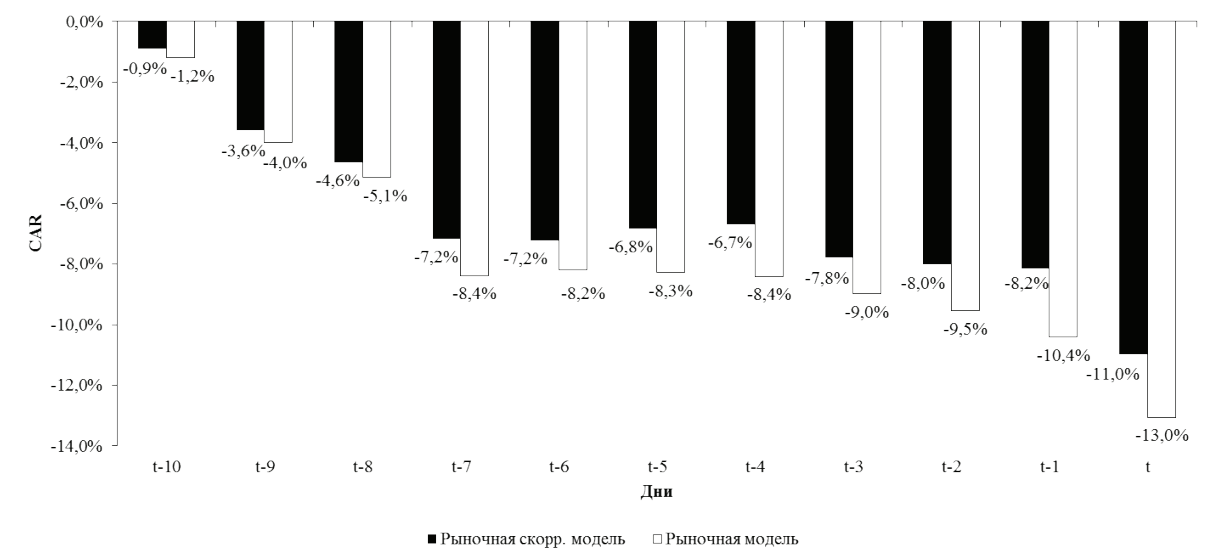

Рисунок 2. Динамика накопленной избыточной доходности в случаях административного давления со сторонь представителей силовых структур

Анализ результатов, представленных в табл. 3 и 4, позволяет сделать вывод о том, что масштабы инсайдерской торговли в случаях административного давления на бизнес со стороны силовых структур, в среднем, превышают масштабы инсайдерской торговли в случаях административного давления со стороны представителей власти.

Из табл. 4 видно, что избыточная доходность в период, предшествующий случаям административного давления на бизнес со стороны представителей ФАС, составила $-3,9 \% \ldots-4,4 \%$ в зависимости от используемой модели оценки затрат избыточной доходности. Таким образом, можно сделать вывод о наличии инсайдерской торговли при административном давлении данного типа.

$\sqcup$ Примером является заявление руководителя ФАС Игоря Артемьева от 26.02.2014 о необходимости запрета на территории России универсальных систем тарифообразования авиабилетов (новость - 3.4), после которого стоимость акций «Аэрофлота» снизилась на 8,4\%. Совокупная избыточная доходность акций компании «Аэрофлот» за 10 дней, предшествовавших заявлению руководителя ФАС, в этом случае составила $-3,80 \%--3,84 \%$ в зависимости от используемой модели. 
Результаты исследования накопленной избыточной доходности в случаях административного давления со стороны представителей ФАС

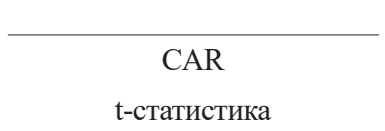

Количество наблюдений Справочно:

Рыночная модель
$-3,9 \%$ ***
51,69

320

\section{Скорректированная рыночная модель}

$$
\begin{gathered}
-4,4 \% * * * \\
44,73
\end{gathered}
$$

320

$-0,1 \%$

*** - результат значим на 1\%-ном уровне.

** - результат значим на 5\%-ном уровне.

* - результат значим на 10\%-номуровне.

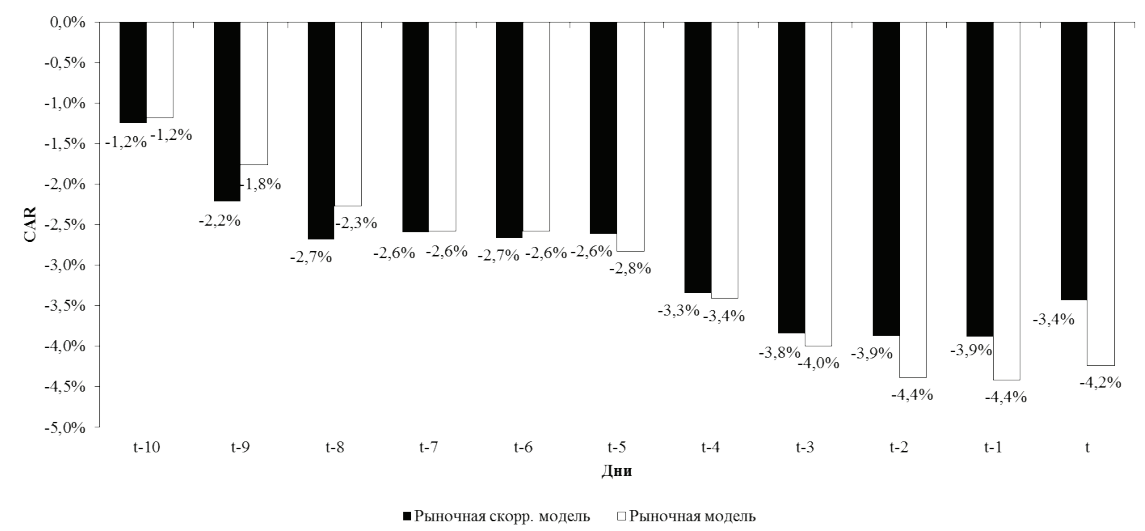

Рисунок 3. Динамика накопленной избыточной доходности в случаях административного давления со стороны представителей ФАС

Еще одна новость в данной группе также касается компании «Аэрофлот»: 12.12.2008 Федеральная антимонопольная служба направила письмо в Правительство РФ с предложением лишить компанию платежей за пролеты иностранных самолетов по транссибирским маршрутам (новость 3.11). Совокупная избыточная доходность акций компании за 10 дней, предшествовавших этому событию, составила $-10,2 \% \ldots-15,5 \%$ в зависимости от используемой модели оценки затрат избыточной доходности.

Анализ результатов, представленных в табл. 2 и 4, позволяет сделать вывод о том, что масштабы инсайдерской торговли в случаях административного давления на бизнес со стороны представителей ФАС, в среднем, превышают масштабы инсайдерской торговли в случаях административного давления со стороны представителей власти.

Проверка гипотезы 2. Из данных в табл. 5 следует, что избыточная доходность по результатам применения двух моделей оценки избыточной доходности составляет $-2,3 \% \ldots-4,0 \%$ в периоды, предшествовавшие случаям административного давления на бизнес со стороны представителей ФНС, что говорит о наличии инсайдерской торговли при административном давлении данного типа.

Таблица 5

Результаты исследования накопленной избыточной доходности в случаях административного давления со стороны представителей ФНС

$\frac{\text { CAR }}{\text { t-статистика }}$

Количество наблюдений

Справочно:

Рыночная модель
$-4,0 \% * * *$
41,65

220

$-0,2 \%$

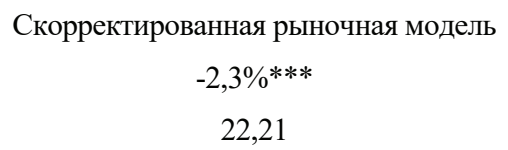

Скорректированная рыночная модель $-2,3 \% * * *$

22,21

220

$-0,2 \%$

*** - результат значим на 1\%-ном уровне. $\quad$ ** - результат значим на 5\%-ном уровне. * - результат значим на 10\%-номуровне. 
В частности, совокупная избыточная доходность за 10 дней, предшествовавших появлению новости от 30.01.2009 о том, что Межрегиональная инспекция ФНС №3 по крупнейшим налогоплательщикам предъявила налоговые претензии к компании «Уралкалий» на 803 млн руб. (новость 4.7), составила $-9,1 \%--13,5 \%$ в зависимости от применяемой модели определения избыточной доходности. Впоследствии предъявляемые обвинения были сняты.

Совокупная избыточная доходность акций компании «Мечел» за 10 дней, предшествовавших

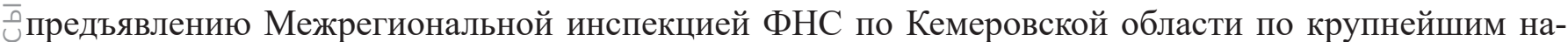
логоплательщикам налоговых претензий компании в размере 1,3 млрд. руб. составила 1,4\% - -4,3\% в зависимости от применяемой модели.

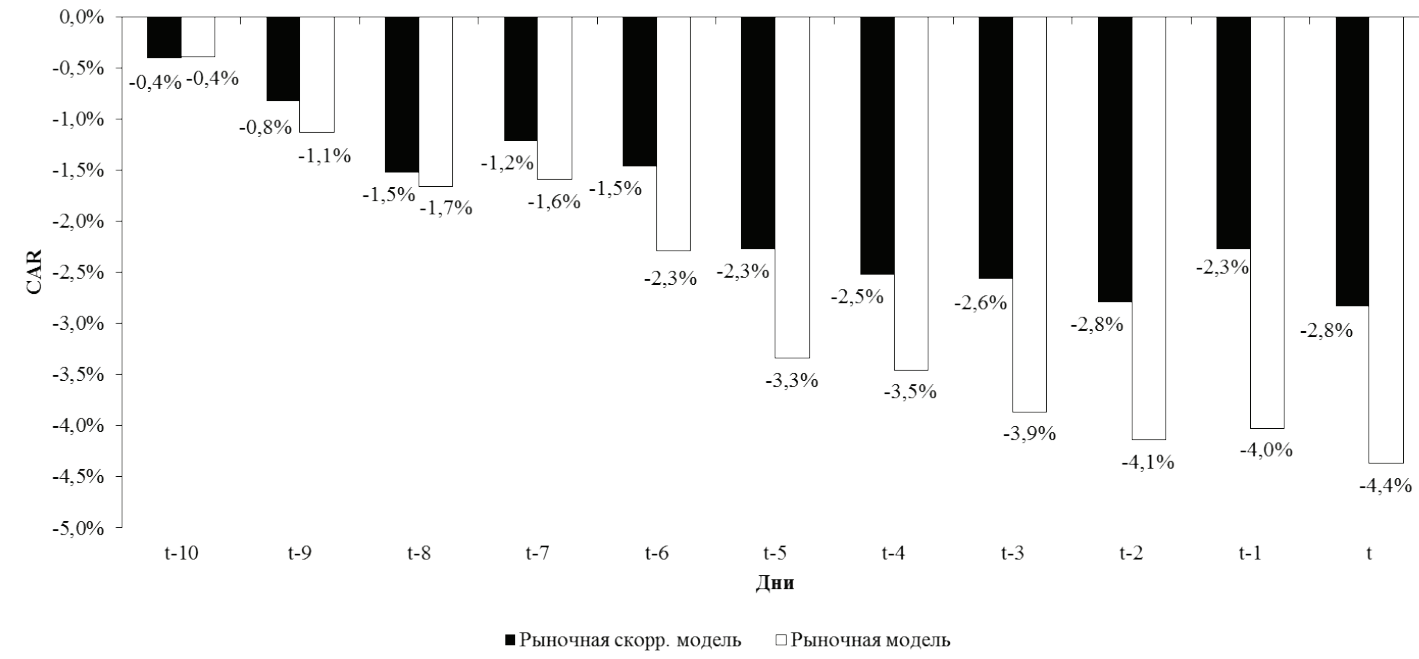

Рисунок 4. Динамика накопленной избыточной доходности в случаях административного давления со сторонь представителей ФНС

Анализ результатов, представленных в табл. 2 и 5, позволяет сделать вывод о том, что масштабы инсайдерской торговли в случаях административного давления на бизнес со стороны представителей ФНС, в среднем, превышают масштабы инсайдерской торговли в случаях административного давления со стороны представителей власти.

Таким образом, гипотеза 1 была нами подтверждена частично.

В статье [Чиркова, Агамян, 2015] авторы, анализируя инсайдерскую торговлю в период до объявлении о сделках M\&A в 2006 - 2013 гг., приходят к выводу о том, что на период до объявления (появления слухов) о сделке приходится две трети роста CAR, тогда как в США - только треть.

Таблица 6

Результаты анализа доли роста CAR, приходящейся на период, предшествующий административному давлению на бизнес со стороны представителей власти

$\begin{array}{cc}\text { Группа } & \text { Доля \% } \\ \text { Представители власти } & 13-18 \\ \text { Представители силовых структур } & 77-81 \\ \text { Представители ФАС } & 47-50 \\ \text { Представители ФНС } & 50-63 \\ \text { В среднем по всем группам } & 47-52\end{array}$

Из табл. 6 видно, что доля избыточной доходности, реализованной в период, предшествующий случаям административного давления на бизнес составила, в среднем, 47 - 52\% для всех групп в зависимости от используемой модели оценки затрат избыточной доходности. При этом особо стоит выделить группу событий «представители силовых структур», в рамках которой доля CAR, приходящаяся на период, предшествующий административному давлению на бизнес составила $77-81 \%$, что свидетельствует о наличии масштабной инсайдерской торговли. В свою очередь, в 
рамках группы «представители исполнительной и законодательной власти» инсайдерская торговля практически отсутствует.

Проверка гипотезы 2. Анализ результатов, представленных в табл. 6 позволяет сделать вывод о том, что реакция рынка на административное давление на бизнес со стороны представителей вла־- сти превышает аналогичную реакцию в случаях административного давления на бизнес со сторо글 представителей ФНС и ФАС и различных силовых структур.

Таблииа 6

Результаты исследования накопленной избыточной доходности и реакции рынка на случаи административного давления со стороны представителей различных государственных служб

Представители исполнительной и законодательной

CAR

Доходность акции в

(1)

$$
\text { власти }
$$

$-0,4 \% \ldots-0,6 \%$

$-2,8 \%$

Представители силовых структур

$-8,2 \% \ldots-10,4 \%$

$-2,4 \%$

Представители ФАС

$-3,9 \% \ldots-4,4 \%$

$-0,1 \%$

Представители ФНС

$-2,3 \% \ldots-4,0 \%$

$-0,2 \%$

Таким образом, гипотеза 2 была нами подтверждена.

Проверка гипотезы 3. Анализ результатов, представленных в табл. 7 позволяет сделать вывод о бом, что вступление в силу закона №224-Ф3 «О противодействии неправомерному использованию инсайдерской информации и манипулированию рынком» в январе 2011 г. не способствовало уменьшению масштабов инсайдерской торговли на российском фондовом рынке. Более того, начиная с 2013 г., ее масштабы заметно увеличились.

Таблица 7

Результаты исследования накопленной избыточной доходности и реакции рынка на случаи административного давления со стороны представителей различных государственных служб до и после ужесточения законодательства в сфере противодействия инсайдерской торговле

Таким образом, гипотеза 3 не была нами подтверждена.

\begin{tabular}{c|c} 
Период & CAR \\
$27.07 .2013-31.12 .2014$ & $-4,6 \% \ldots-5,8 \%$ \\
$27.07 .2011-26.07 .2013$ & $0,1 \% \ldots . .0,8 \%$ \\
$01.07 .2010-26.07 .2011$ & $-0,1 \% \ldots-1,1 \%$ \\
$01.01 .2000-01.07 .2010$ & $-3,1 \% \ldots-4,0 \%$
\end{tabular}

\section{Заключение}

В рамках данной работы нами было продиагностировано наличие инсайдерской торговли в периоды, предшествующие случаям административного давления на бизнес со стороны представителей различных государственных служб в 2000-2014 гг. Проведенный анализ подтвердил наличие инсайдерской торговли при данном типе событий в рассматриваемый период.

В результате проведенного анализа нам не удалось обнаружить масштабной инсайдерской торговли в периоды, предшествующие случаям административного давления на бизнес со стороны представителей исполнительной и законодательной власти Российской Федерации. При этом наблюдаемая реакция рынка на события данного типа была максимальной.

Нами было диагностировано наличие значительной по масштабам инсайдерской торговли в периоды, предшествующие случаям административного давления на бизнес со стороны представителей силовых структур. Реакция рынка на случаи административного давления данного типа была значительной.

Еще одним результатом исследования стало обнаружение инсайдерской торговли в периоды, предшествующие случаям административного давления на бизнес со стороны представителей ФНС 
и ФАС, причем масштабы этой торговли были значительно меньше по сравнению со случаями административного давления со стороны представителей различных силовых структур. Это может говорить о большей силе административного ресурса силовых структур по сравнению с административным ресурсом «надзорных и контрольных» служб исполнительной власти в Российской Федерации.. Реакция рынка на данные события была незначительной.

Также нами обнаружено, что вступление в силу Закона №224-Ф3 «О противодействии неправомерному использованию инсайдерской информации и манипулированию рынком» в январе 2011 г. не привело к желаемому результату и масштабы инсайдерской торговли на российском рынке акций увеличились.

шПредметом дальнейшего исследования может быть диагностирование декларируемой торговли корпоративных инсайдеров на более широкой выборке данных российских компаний.

\section{Список литературы:}

1. Чиркова Е., Агамян Г. Инсайдерская торговля на российском фондовом рынке перед объявлениями о сделках по слияниям и поглощениям // Экономический журнал ВШЭ. 2015. № 3, т. 19. С. 395-422.

2. Чиркова Е., Петров В. Диагностирование инсайдерской торговли в период конфликта акционеров ОАО «ВымпелКом в 2005-2013 годах // Экономическая политика. 2015. № 2, т. 10. C. $151-173$.

3. Agarwal, M., and Singh, H. (2006) "Merger announcements and insider trading activity in India: an empirical investigation", Investment Management and Financial Innovations, Vol. 3. No. 1, pp. $140-154$.

4. Betzer, A., and Theissen, E. (2009), "Insider trading and corporate governance: the case of Germany”, European Financial Management, Vol. 15. No. 2, pp. 402-429.

5. Bhattacharya, U., and Dauk, H. (2002), "The world price of insider trading", The Journal of Finance, Vol. 57. No 1, pp. 75-180.

6. Cheuk, M.-Y., Fan, D.K.. and So, R.W. (2006), "Insider trading in Hong Kong: some stylized facts", Pacific-Basin Finance Journal, Vol. 14. No. 1, pp. 73-90.

7. Ching, K., Firth, M., and Rui, O. (2006), "The information content of insider trading around seasoned equity offerings", Pacific-Basin Finance Journal, Vol. 14. No. 1, pp. 91-117.

8. Clements, M., and Singh, H. (2011), "An analysis of trading in large stocks before successful takeover announcements", Journal of Multinational Financial Management, Vol. 21. No. 1, pp. $1-17$.

9. Degryse, H., Jong, F., and Lefebvre, J. (2009), “An empirical analysis of legal insider trading in the Netherlands". SSRN Working Paper. Available at SSRN: http://ssrn.com/abstract=1430283

10. Del Brio, E.B., Miguel, A., and Perote, J. (2002), "An investigation of insider trading profits in the Spanish stock market”, The Quarterly Review of Economics and Finance, Vol. 42. No 1, pp. 73-94.

11. Eckbo, E.B., and Smith, D. (1999) “The conditional performance of insider trades". The Journal of Finance, Vol. 53. No. 2, pp. 467-498.

12. Etebari, A., Tuirani-Rad, A., and Gilbert, A. (2004), "Disclosure regulation and the profitability of insider trading: evidence from New Zealand”, Pacific-Basin Finance Journal, Vol. 12. No. 5, pp. 479-502.

13. Finnerty, J.E. (1976), "Insiders and market efficiency", Journal of Finance, Vol. 31. No. 4, pp. 1141-1148.

14. Fidrmuc, J., Goergen, M., and Renneboog, L. (2006), "Insider trading, news releases and ownership concentration", Journal of Finance, Vol. 61. No. 6, pp. 2931-2973.

15. Gurgul, H., and Majdosz, P. (2007), "The informational content of insider trading disclosures: 
empirical results for the Polish stock market", Central European Journal of Operations Research, Vol. 15. No. 1, pp. 1-19.

16. Jabbour, A.R., Jalilvand, F., and Switzer, J. (2000) "Pre-bid price run-ups and insider trading activity: evidence from Canadian acquisitions", International Review of Financial Analysis, Vol. 9. No. 1, pp. 404-422.

17. Jaffe, J.F. (1974), "The effect of regulation changes on insider trading", The Bell Journal of Economics and Management Science, Vol. 5. No. 1, pp. 93-121.

18. Jaffe, J.F. (1974), "Special information and insider trading”, The Journal of Business, Vol. 47. No. 3 , pp. 410-428.

19. Jarrell, A.G., and Pinkerton, A. (1989), "Stock trading before the announcement of tender offers: insider trading or market anticipation", Journal of Law, Economics, \& Organization, Vol. 5. No. 2, pp. 225-248.

20. Keown, A., and Pinkerton, J. (1981), "Merger announcements and insider trading activity: an empirical investigation", The Journal of Finance, Vol. XXXVI, No. 4, pp. 140-154.

21. King, M., and Roell, A. (1988), "Insider trading”, Economic Policy, Vol. 6, pp. 855-869.

22. Lakonishok, J., and Lee, I. (2001), “Are insider trades informative?”, The Review of Financial Studies, Vol. 14. No. 1, pp. 79-111.

23. Madura, J., and Wiant. K.J. (1995), "Information content of bank insider trading”, Applied Financial Economics, Vol. 5. No. 4, pp. 219-227.

24. Meulbroek, L. (1992), “An empirical analysis of illegal insider trading”, The Journal of Finance, Vol. XLVII, No. 5, pp. 1661-1699.

25. Meulbroek, L., and Hart, C. (1997), "The effect of illegal insider trading on takeover premia", Review of Finance, Vol. 1. No. 1, pp. 51-80.

26. Radd, E., and Wu, H. (1995), "Insider trading effect on stock returns around open-market stock repurchase announcement: an empirical study", The Journal of Financial Research, Vol. 17. No. 1, pp. 45-57.

27. Pope, P.F., Morris, R.C., and Peel, D.A. (1990), "Insider trading, some evidence on market efficiency and directors' share dealings in Great Britain", Journal of Business Finance and Accounting, Vol. 17. No. 3, pp. 359-380.

28. Rozeff, M., and Zaman, M. (1988), "Market efficiency and insider trading", The Journal of Business, Vol. 61. No. 1, pp. 25-44.

29. Seyhun, N.H. (1986), "Insiders' profits, costs of trading and market efficiency”, Journal of Financial Economics, Vol. 16. No. 2, pp. 189-212.

30. Wisniewski, T.P., and Bohl, M. (2005), "The information content of registered insider trading under lax law enforcement", International Review of Law and Economics, Vol. 25. No. 2, pp. 169-185.

31. Wong, M., Chung, Y.L., and Wu, L.F. (2000), "Insider trading in the Hong Kong stock market", Asia-Pacific Financial Markets, Vol. 7. No. 3, pp. 275-288.

32. Zingg, A., Lang, S., and Wyttenbach, D. (2007), "Insider trading in the Swiss stock market", Schweizerische Zeitschrift fur Volkswirtschaft und Statistik, Vol. 143. No. 1, pp. 333-364. 


\title{
TESTING FOR THE INSIDER TRADING PRIOR \\ TO THE CASES OF ADMINISTRATIVE PRESSURE
}

\begin{abstract}
Elena Chirkova,
Associate professor, Department of Finance,

Faculty of Economics, National Research University Higher School of Economics
\end{abstract}

Vladislav Petrov,

Postgraduate student, Department of Finance,

Faculty of Economics, National Research University Higher School of Economics

\begin{abstract}
This article presents the results of a study of insider trading prior to the cases of administrative pressure on the Russian public companies. The study is based on an analysis of cumulative abnormal returns during the period prior to the publication of a news. In the study we analyzed 71 news about the administrative pressure.

${ }^{x}$ We have not found the presence of a large-scale insider trading prior to the administrative pressure on business by the representatives of executive and legislative authorities of the Russian Federation. The - cumulative abnormal return (CAR) amounted $-0,4 \%--0,6 \%$ depending on utilized model. We found a $\checkmark$ large-scale insider trading prior to the to the administrative pressure on business by the representatives of Esecurity agencies $(\mathrm{CAR}=-8,2 \%--10,4 \%)$. Market reaction was significant in both cases.

${ }_{\nabla}$ Also we detected a small-scale insider trading prior to the administrative pressure on business by the ํㅏrepresentatives of Federal Tax Service and Federal Antimonopoly Service $(-2,3 \%--4,4 \%$ and $-3,9 \%-$ $\smile-4,4 \%$ respectively). Meanwhile, the market reaction was insignificant in both of these cases.
\end{abstract}

Key words: insider trading, cumulative abnormal return, administrative pressure.

JEL: G10, G14, G19.

\section{References}

1. Chirkova E. and Agamian G. (2015), "Insider trading in the Russian stock market before the announcements of mergers and acquisitions deals”, HSE Economic Journal, Vol 19, № 3, pp. 395422.

2. Chirkova E. and Petrov V. (2015), "The diagnosis of the insider trading during the conflict of shareholders of "VimpelCom" in 2005-2013", Ekonomicheskaya Politika, Vol 10, № 2, pp. 151-173.

3. Agarwal M. and Singh H. (2006) "Merger announcements and insider trading activity in India: an empirical investigation", Investment Management and Financial Innovations, Vol. 3, No 1, pp. $140-154$.

4. Betzer A. and Theissen E. (2009), "Insider trading and corporate governance: the case of Germany", European Financial Management, Vol. 15. No 2, pp. 402-429.

5. Bhattacharya U. and Dauk H. (2002), "The world price of insider trading", The Journal of Finance, Vol. 57. No 1, pp. 75-180.

6. Cheuk M.-Y., Fan D. K. and So R. W. (2006), “Insider trading in Hong Kong: some stylized facts", Pacific-Basin Finance Journal, Vol. 14. No 1, pp. 73-90.

7. Ching K., Firth M. and Rui O. (2006), "The information content of insider trading around seasoned equity offerings", Pacific-Basin Finance Journal, Vol. 14. No. 1, pp. 91-117.

8. Clements M. and Singh H. (2011), "An analysis of trading in large stocks before successful takeover announcements", Journal of Multinational Financial Management, Vol. 21. No 1, pp. 1-17.

9. Degryse H., Jong F. and Lefebvre J. (2009), “An empirical analysis of legal insider trading in the 
Netherlands”. SSRN Working Paper. Available at SSRN: http://ssrn.com/abstract=1430283

10. Del Brio E. B., Miguel A. and Perote J. (2002), "An investigation of insider trading profits in the Spanish stock market", The Quarterly Review of Economics and Finance, Vol. 42. No 1, pp. 73-94.

11. Eckbo E. B. and Smith D. (1999) "The conditional performance of insider trades". The Journal of Finance, Vol. 53. No 2, pp. 467-498.

12. Etebari A., Tuirani-Rad A. and Gilbert A. (2004), "Disclosure regulation and the profitability of insider trading: evidence from New Zealand”, Pacific-Basin Finance Journal, Vol. 12. No 5, pp. 479-502.

13. Finnerty J. E. (1976), "Insiders and market efficiency", Journal of Finance, Vol. 31. No 4, pp. 1141-1148.

14. Fidrmuc J., Goergen M. and Renneboog L. (2006), "Insider trading, news releases and ownership concentration", Journal of Finance, Vol. 61. No 6, pp. 2931-2973.

15. Gurgul H. and Majdosz P. (2007), "The informational content of insider trading disclosures: empirical results for the Polish stock market", Central European Journal of Operations Research, Vol. 15. No 1, pp. 1-19.

16. Jabbour A. R., Jalilvand F. and Switzer J. (2000) "Pre-bid price run-ups and insider trading activity: evidence from Canadian acquisitions", International Review of Financial Analysis, Vol. 9. No 1, pp. 404-422.

17. Jaffe J. F. (1974) "The effect of regulation changes on insider trading", The Bell Journal of Economics and Management Science, Vol. 5. No 1, pp. 93-121.

18. Jaffe J. F. (1974), "Special information and insider trading”, The Journal of Business, Vol. 47. No 3, pp. 410-428.

19. Jarrell A. G. and Pinkerton A. (1989), "Stock trading before the announcement of tender offers: insider trading or market anticipation", Journal of Law, Economics, \& Organization, Vol. 5. No 2, pp. 225-248.

20. Keown A. and Pinkerton J. (1981), "Merger announcements and insider trading activity: an empirical investigation", The Journal of Finance, Vol. XXXVI, No 4, pp. 140-154.

21. King M. and Roell. A. (1988), “Insider trading”, Economic Policy, Vol. 6, pp. 855-869.

22. Lakonishok J. and Lee I. (2001) “Are insider trades informative?”, The Review of Financial Studies, Vol. 14. No 1, pp. 79-111.

23. Madura J. and Wiant K. J. (1995) "Information content of bank insider trading", Applied Financial Economics, Vol. 5. No 4, pp. 219-227.

24. Meulbroek L. (1992), "An empirical analysis of illegal insider trading”, The Journal of Finance, Vol. XLVII, No 5, pp. 1661-1699.

25. Meulbroek L. and Hart C. (1997), "The effect of illegal insider trading on takeover premia”, Review of Finance, Vol. 1. No 1, pp. 51-80.

26. Radd, E. and Wu H. (1995), "Insider trading effect on stock returns around open-market stock repurchase announcement: an empirical study", The Journal of Financial Research, Vol. 17. No. 1, pp. 45-57.

27. Pope P. F., Morris R. C. and Peel D. A. (1990), "Insider trading, some evidence on market efficiency and directors' share dealings in Great Britain", Journal of Business Finance and Accounting, Vol. 17. No 3, pp. 359-380.

28. Rozeff M. and Zaman M. (1988), "Market efficiency and insider trading", The Journal of Business, Vol. 61. No 1, pp. 25-44.

29. Seyhun N. H. (1986), "Insiders' profits, costs of trading and market efficiency”, Journal of Financial Economics, Vol. 16. No 2, pp. 189-212.

30. Wisniewski T.P. and Bohl M. (2005), "The information content of registered insider 
trading under lax law enforcement", International Review of Law and Economics, Vol. 25. No 2, pp. 169-185.

31. Wong M., Chung Y. L. and Wu L. F. (2000), "Insider trading in the Hong Kong stock market", Asia-Pacific Financial Markets, Vol. 7. No 3, pp. 275-288.

32. Zingg A., Lang S. and Wyttenbach D. (2007), "Insider trading in the Swiss stock market", Schweizerische Zeitschrift fur Volkswirtschaft und Statistik, Vol. 143. No 1, pp. 333-364. 
Приложение 1.

\section{Список новостей}

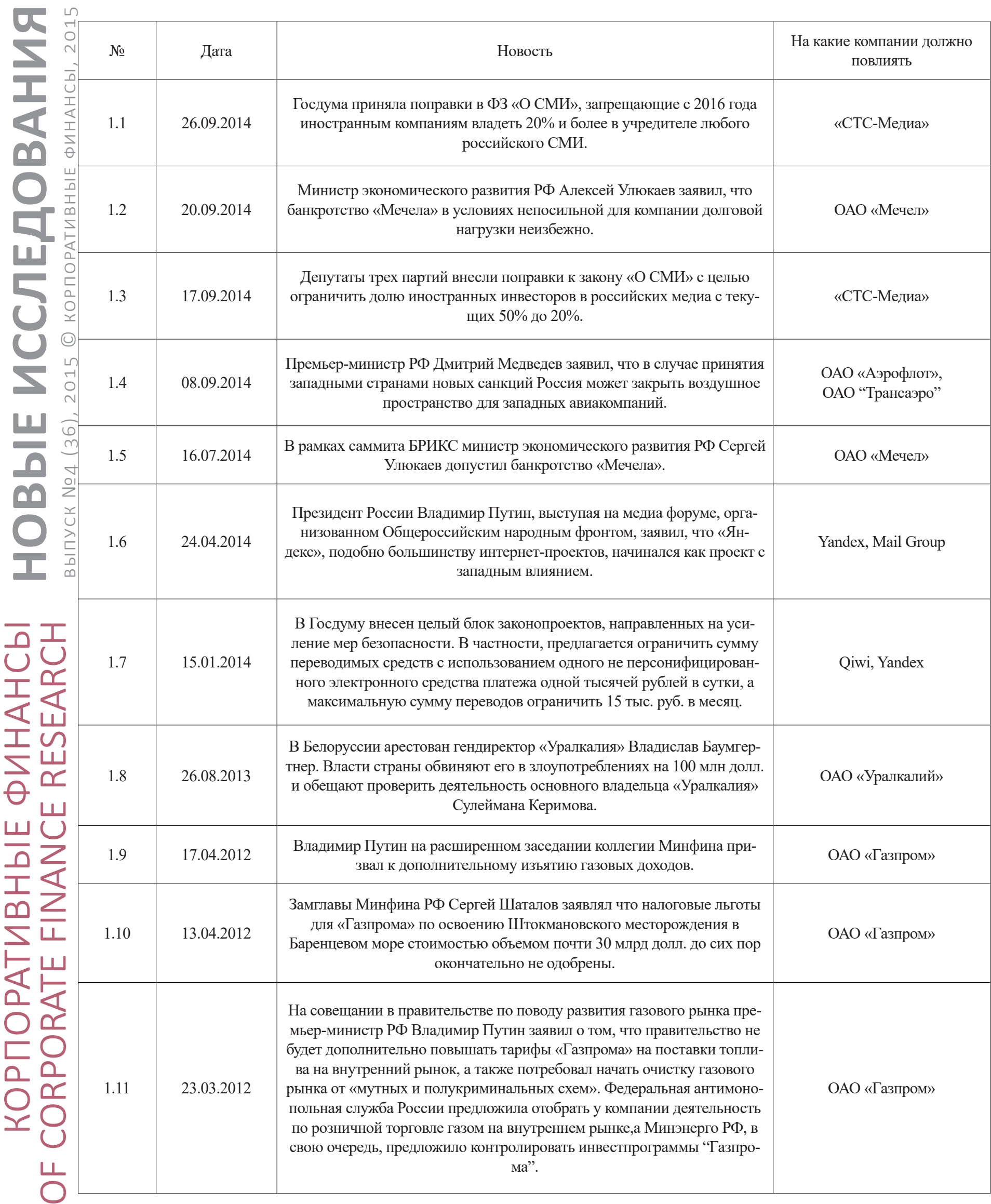




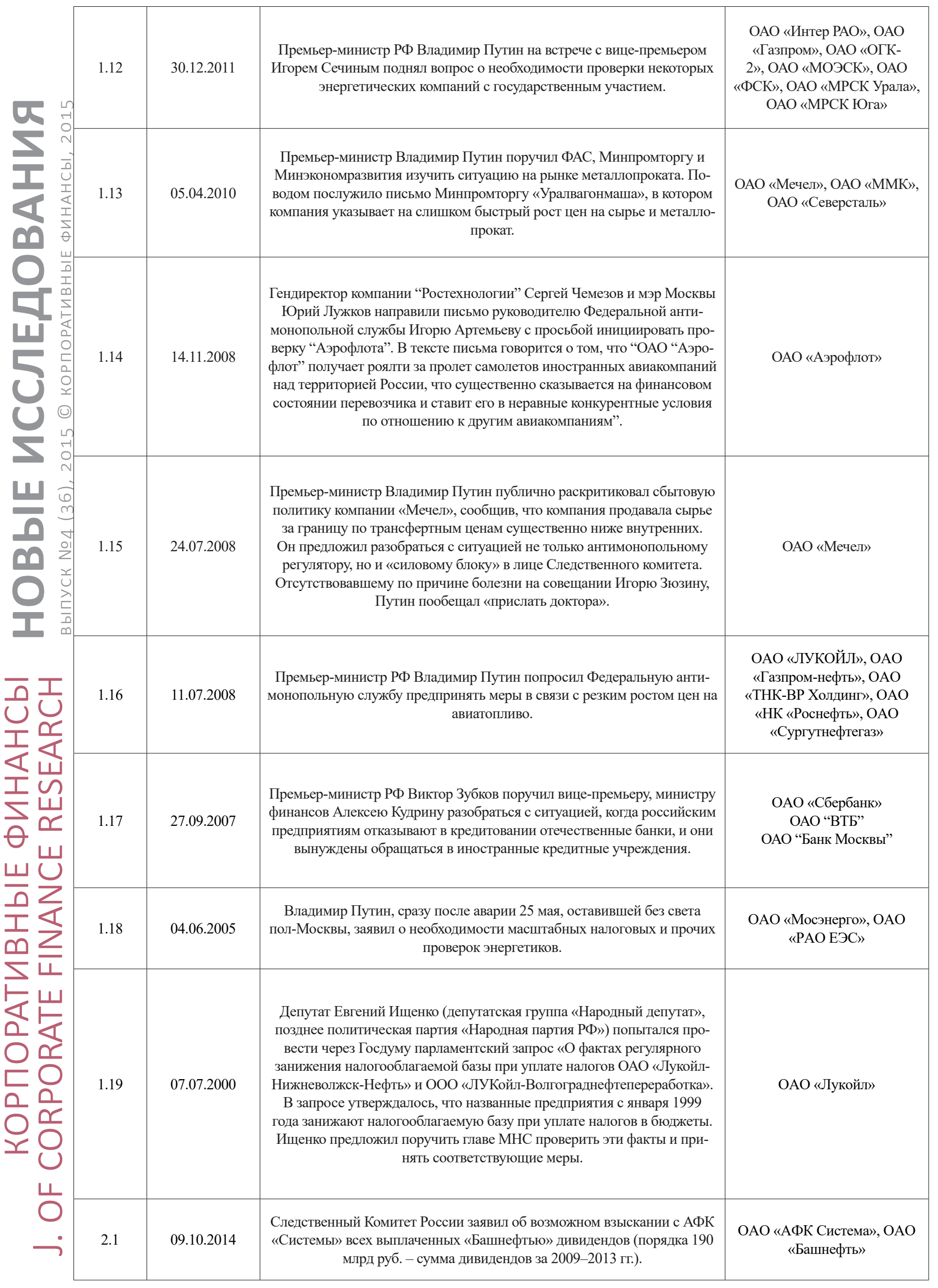




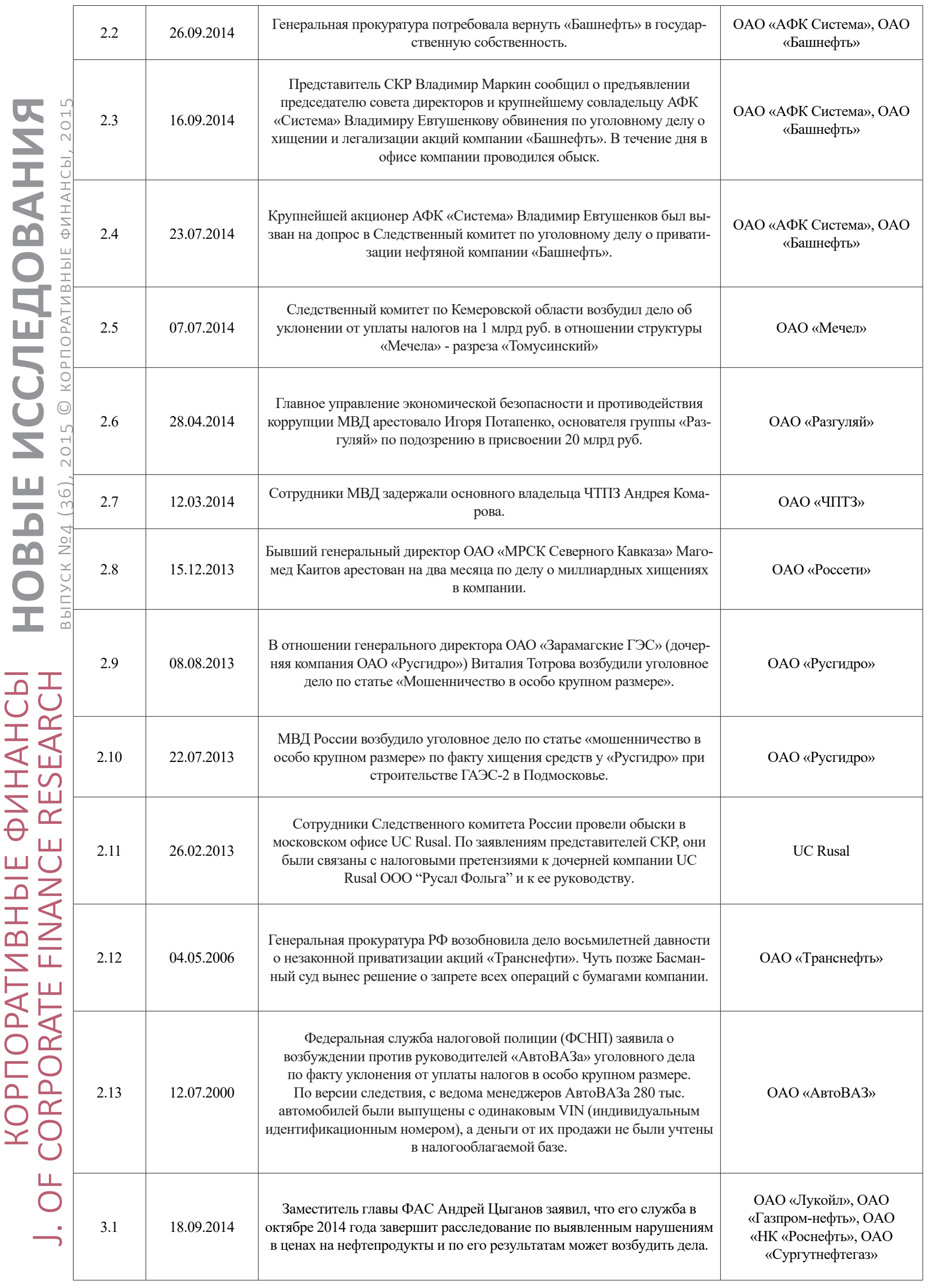




\begin{tabular}{|c|c|c|c|c|}
\hline & 3.2 & 02.09 .2014 & $\begin{array}{c}\text { ФАС подозревает «Русгидро» и General Electric в сговоре при } \\
\text { проведении торгов на закупку газотурбинной установки для Якутской } \\
\text { ГРЭС-2. }\end{array}$ & ОАО «Русгидро» \\
\hline 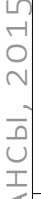 & 3.3 & 12.08 .2014 & $\begin{array}{c}\text { Начальник управления контроля топливно-энергетического комплекса } \\
\text { ФАС Дмитрий Махонин заявил что, не исключает возбуждения дел про- } \\
\text { тив нефтяных компаний в связи с наблюдающимся в последние недели } \\
\text { ростом цен на бензин. }\end{array}$ & $\begin{array}{c}\text { ОАО «Лукойл», ОАО } \\
\text { «Газпром-нефть», ОАО } \\
\text { «К «Роснефть», ОАО } \\
\text { «Сургутнефтегаз» }\end{array}$ \\
\hline $\begin{array}{l}x \\
\frac{1}{\partial} \\
\theta \\
\bar{\nu}\end{array}$ & 3.4 & 26.02.2014 & $\begin{array}{c}\text { Руководитель ФАС Игорь Артемьев заявил о необходимости запрета на } \\
\text { территории России универсальных систем тарифообразования авиаби- } \\
\text { летов. }\end{array}$ & $\begin{array}{l}\text { ОАО «Аэрофлот», } \\
\text { ОАО “Трансаэро", } \\
\text { ОАО "Ютэйр" }\end{array}$ \\
\hline 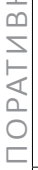 & 3.5 & 23.04.2013 & $\begin{array}{c}\text { Подмосковное управление ФАС наложило на авиакомпанию «Аэро- } \\
\text { флот» штраф в размере } 8 \text { млн руб. за нарушение антимонопольного } \\
\text { законодательства в соглашении о стратегическом партнерстве с аэропор- } \\
\text { том «Шереметьево» }\end{array}$ & ОАО «Аэрофлот» \\
\hline 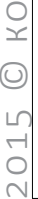 & 3.6 & 03.04 .2013 & $\begin{array}{c}\text { Руководитель ФАС Игорь Артемьев заявил о решении возбудить дело } \\
\text { против ОАО «Газпром» и его крупнейшего поставщика труб большого } \\
\text { диаметра - «Северного европейского трубного проекта» по подозрению } \\
\text { в нарушении антимонопольного законодательства. }\end{array}$ & ОАО «Газпром» \\
\hline 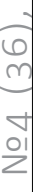 & 3.7 & 28.09.2012 & $\begin{array}{c}\text { Федеральная антимонопольная служба России возбудила дело против } \\
\text { нескольких «дочек» «Евраза», обвинив группу в продаже железнодо- } \\
\text { рожных рельсов некоторым компаниям в ряде стран СНГ по занижен- } \\
\text { ным ценам }\end{array}$ & EVRAZ \\
\hline 글 & 3.8 & 19.08.2012 & $\begin{array}{c}\text { Федеральная антимонопольная служба России возбудила дело против } \\
\text { «Ростелекома» на основании жалоб других операторов на значительное } \\
\text { завышение госкомпанией цен на доступ к кабельной канализации. }\end{array}$ & ОАО «Ростелеком» \\
\hline & 3.9 & 18.07.2012 & $\begin{array}{c}\text { ФАС заподозрила МОЭК (подконтрольна «Газпром энергохолдинг») в } \\
\text { превышении установленного тарифа на отопление. }\end{array}$ & OAO «Газпром» \\
\hline & 3.10 & 27.10 .2009 & $\begin{array}{c}\text { ФАС России оштрафовала ОАО «НК «Роснефты» на 5,280 млрд руб. за } \\
\text { злоупотребление доминирующим положением на оптовом рынке не- } \\
\text { фтепродуктов в первой половине } 2009 \text { года. }\end{array}$ & ОАО «НК «Роснефть» \\
\hline & 3.11 & 12.12 .2008 & $\begin{array}{c}\text { Федеральная антимонопольная служба направила письмо в правитель- } \\
\text { ство РФ, в котором предложило лишить национального перевозчика } \\
\text { платежей за пролеты иностранных самолетов по транссибирским } \\
\text { маршрутам. Вместо этого она предложила осуществить целевое исполь- } \\
\text { зование этих платежей для модернизации системы аэронавигационного } \\
\text { обслуживания. }\end{array}$ & ОАО «Аэрофлот» \\
\hline & 3.12 & 27.10 .2008 & $\begin{array}{c}\text { ФАС России признало ОАО «Лукойл» нарушившим антимонопольное } \\
\text { законодательство. }\end{array}$ & ОАО «ЛукойЛ» \\
\hline & 3.13 & 26.10 .2008 & $\begin{array}{c}\text { ФАС России признало «Газпромнефть» и «ТНК-ВР Холдингґ нарушив- } \\
\text { шим антимонопольное законодательство. }\end{array}$ & $\begin{array}{l}\text { ОАО «Газпром-нефть», } \\
\text { ОАО “ТНК-ВР Холдинг” }\end{array}$ \\
\hline & 3.14 & 29.07.2008 & $\begin{array}{c}\text { Во вторник ФАС приняла решение о возбуждении двух дел в отноше- } \\
\text { нии ООО «Распадский уголь» и ООО «Евраз холдинг» по признакам } \\
\text { нарушения закона о защите конкуренции. }\end{array}$ & ОАО «Распадская» \\
\hline & 3.15 & 15.07.2008 & $\begin{array}{l}\text { Федеральная антимонопольная служба возбудила дела в отношении сра- } \\
\text { зу пяти нефтяных компаний: ОАО «ЛУКОЙЛ», ОАО «Газпром нефть», } \\
\text { ОАО «ТНК-ВР Холдинг», ОАО «НК «Роснефть», ОАО «Сургутнефте- } \\
\text { газ». Им вменяется в вину злоупотребление доминирующим положени- } \\
\text { ем на рынке. }\end{array}$ & $\begin{array}{l}\text { ОАО “Лукойл”, ОАО } \\
\text { “Газпром-нефть”, ОАО } \\
\text { "ТНК-ВР Холдинг”, ОАО } \\
\text { "НК “Роснефть”, ОАО } \\
\text { “Сургутнефтегаз” }\end{array}$ \\
\hline
\end{tabular}




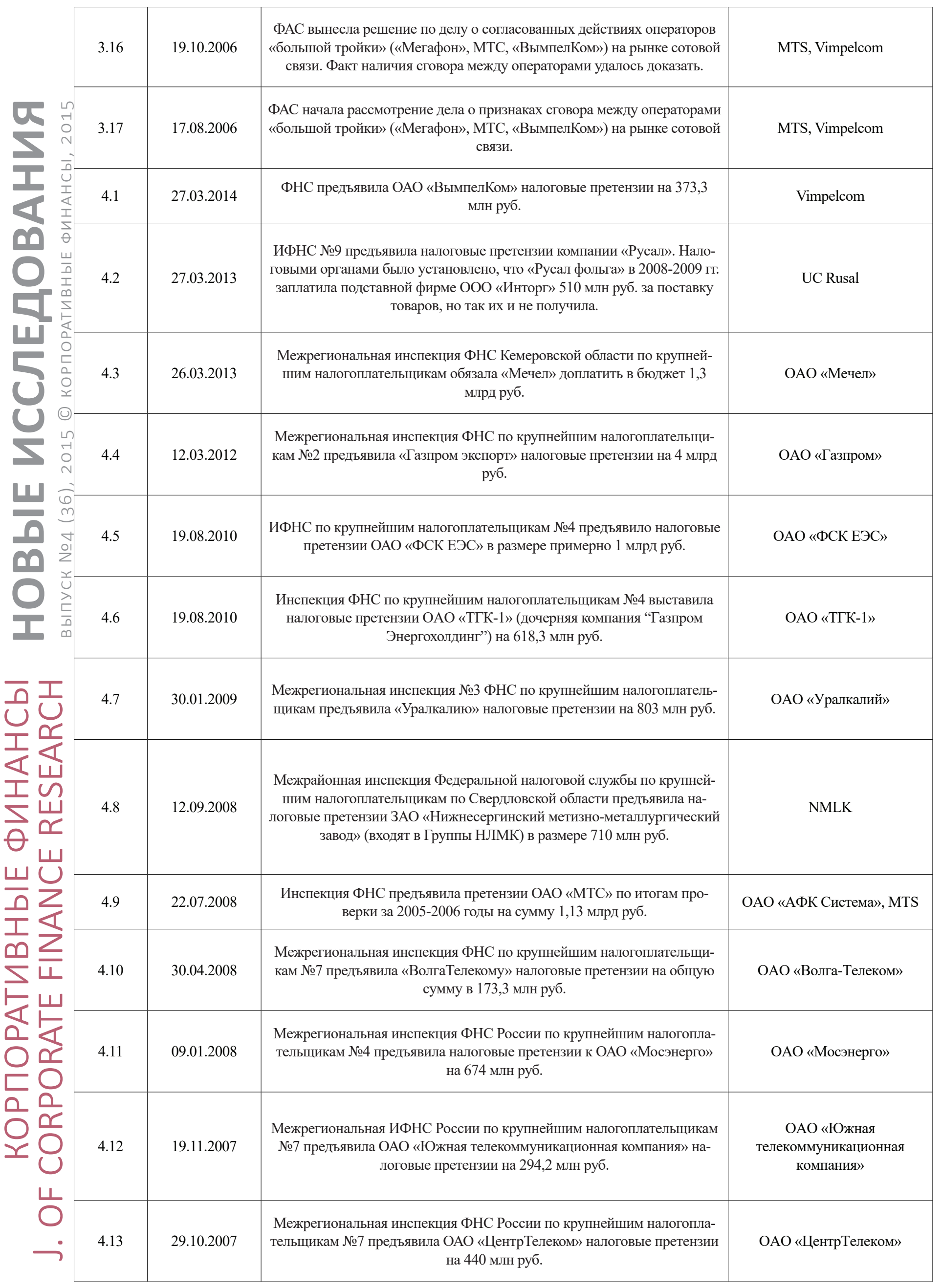




\begin{tabular}{|c|c|c|c|c|}
\hline & 4.14 & 14.04.2007 & $\begin{array}{c}\text { Межрегиональная инспекции ФНС по крупным налогоплательщикам } \\
\text { №4 предъявила налоговые претензии РАО «ЕЭС России» на сумму } \\
\text { 1,417 млрд руб. }\end{array}$ & OAО «PAO ЕЭС» \\
\hline 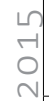 & 4.15 & 14.12.2006 & $\begin{array}{l}\text { ФНС России предъявила ОАО «Акрон» налоговые претензии в размере } \\
\qquad 1,244 \text { млрд руб. }\end{array}$ & ОАО «Акрон» \\
\hline $\begin{array}{l}-\overrightarrow{1} \\
\underline{U} \\
\underline{I}\end{array}$ & 4.16 & 31.10 .2006 & $\begin{array}{c}\text { ФНС России предъявила ОАО «Уралсвязьинформ» налоговые претен- } \\
\text { зии на общую сумму } 690 \text { млн руб. }\end{array}$ & ОАО «Уралсвязьинформ» \\
\hline $\begin{array}{l}\frac{1}{2} \\
\frac{1}{\theta} \\
\theta\end{array}$ & 4.17 & 31.10 .2006 & $\begin{array}{c}\text { ФНС России предъявила ОАО «МТС» налоговые претензии на 1,284 } \\
\text { млрд руб. }\end{array}$ & MTS \\
\hline 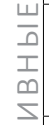 & 4.18 & 11.09 .2006 & $\begin{array}{c}\text { ФНС России предъявила Магнитогорскому меткомбинату (входит в } \\
\text { группу ММК) налоговые претензии на } 12 \text { млн руб. }\end{array}$ & $\mathrm{OAO} « \mathrm{MMK} »$ \\
\hline $\begin{array}{l}- \\
\vdots \\
\vdots \\
\vdots \\
ᄃ\end{array}$ & 4.19 & 25.08 .2006 & $\begin{array}{c}\text { ФНС России предъявила ОАО «Сургутнефтегаз» налоговые претензии } \\
\text { в размере } 1,127 \text { млрд руб. }\end{array}$ & ОАО «Сургутнефтегаз» \\
\hline 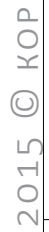 & 4.20 & 09.06 .2006 & $\begin{array}{c}\text { Межрегиональная инспекция ФНС РФ по крупнейшим налогоплатель- } \\
\text { щикам №5 предъявила налоговые претензии российскому концерну } \\
\text { «ВСМПО-Ависма» на сумму 2,656 млрд руб. }\end{array}$ & ОАО «ВСМПО-Ависма» \\
\hline$\frac{1}{3}$ & 4.21 & 26.04 .2006 & $\begin{array}{c}\text { ФНС России предъявила ОАО «ЦентрТелеком» налоговые претензии на } \\
\text { общую сумму 2,353 млрд руб. }\end{array}$ & ОАО «ЦентрТелеком» \\
\hline$\stackrel{+}{+}$ & 4.22 & 26.12 .2005 & $\begin{array}{c}\text { ФНС России предъявило ОАО «Коршуновский ГОК» (входит в Группу } \\
\text { компаний «Мечел») на общую сумму } 9.4 \text { млн долл. }\end{array}$ & ОАО «Мечел» \\
\hline
\end{tabular}

